Editor's Note: These short reviews of recent JNeurosci articles, written exclusively by students or postdoctoral fellows, summarize the important findings of the paper and provide additional insight and commentary. If the authors of the highlighted article have written a response to the Journal Club, the response can be found by viewing the Journal Club at www.jneurosci.org. For more information on the format, review process, and purpose of Journal Club articles, please see http://jneurosci.org/content/ preparing-manuscript\#journalclub.

\title{
GABAergic Networks in the Prefrontal Cortex and Working Memory
}

\author{
Cristina Bañuelos and Marta Urszula Wołoszynowska-Fraser \\ Laboratory of Behavioral Neuroscience, National Institute on Aging, Biomedical Research Center, National Institutes of Health, Baltimore, Maryland 21224 \\ Review of Yoon et al.
}

\section{Introduction}

Working memory, the ability to briefly store and act on mental representations of information, even when that information is no longer associated with sensory input, is crucial to completing goal-directed behaviors (Goldman-Rakic, 1996; Miller and Cohen, 2001). This type of memory critically depends on the prefrontal cortex, as first described based on neurophysiological and lesion studies in monkeys (Fuster, 1990; Goldman-Rakic, 1990). The ability to maintain information in prefrontal cortex after the sensory stimulus is removed is linked to persistent firing of excitatory glutamatergic pyramidal cells (Goldman-Rakic, 1996), but disruption of GABAergic circuits in the prefrontal cortex can produce profound impairments in working memory (Enomoto et al., 2011). Conversely, pharmacologically targeting this local inhibitory circuitry can reverse age-related working memory deficits (Bañuelos et al., 2014). These results from animal studies suggest a critical role for inhibitory GABAergic circuits in prefrontal cortex-dependent working mem-

Received Jan. 16, 2017; revised March 9, 2017; accepted March 13, 2017. We thank Dr. Peter R. Rapp (National Institute on Aging) for invaluable comments during the preparation of the manuscript.

The authors declare no competing financial interests.

Correspondence should be addressed to Dr. Cristina Bañuelos, 251

Bayview Blvd, Suite 100, Room 097705, Baltimore, MD 21224. E-mail: cristina.banuelos@nih.gov.

DOI:10.1523/JNEUROSCI.0135-17.2017

Copyright $\odot 2017$ the authors $\quad 0270-6474 / 17 / 373989-03 \$ 15.00 / 0$ ory (Murray et al., 2015). Consistent with this, postmortem studies of people with schizophrenia, a psychiatric disorder that is associated with significant working memory deficits, have found reduced levels of GABAergic markers in the dorsolateral prefrontal cortex (Lewis et al., 2005). However, few in vivo human studies have directly linked GABA levels to working memory performance. Therefore, Yoon et al. (2016) explored whether GABA levels in the dorsolateral prefrontal cortex are correlated with individual differences in working memory task performance and working memory load capacity.

Yoon et al. (2016) estimated GABA content within the dorsolateral prefrontal cortex of young-adult volunteers using single-voxel proton magnetic resonance spectroscopy. Participants were then tested on a delayed response working memory task with five trial conditions. All trials followed the cue, delay, probe format, but they differed in the number of cues presented ( 1 vs 2 ), length of delay ( 2 s vs $9 s$ ), and the inclusion of distractors during the delay (no distractor vs $1 \mathrm{~s}$ distractor). This procedure allowed for the assessment of three frequently studied working memory components: memory load, maintenance, and resistance to distraction. Participants performed 28 trials for each condition and accuracy as a function of trial condition was used to calculate a metric for changes in memory load, maintenance, and distraction; a higher value indicated a greater degradation in that component of working memory. The relationship between working memory component values and GABA levels in dorsolateral prefrontal cortex was then assessed for each participant.

Accuracy decreased as the task became more difficult, decreasing from $99.6 \%$ in trials with a single cue and a short delay to $76.0 \%$ for the most difficult condition with two cues, a long delay, and an interpolated distractor. There was a significant relationship between dorsolateral prefrontal cortex GABA levels and working memory load such that individuals with higher GABA levels in the dorsolateral prefrontal cortex performed significantly better on the trials requiring greater memory capacity. There was no significant relationship between dorsolateral prefrontal cortex GABA levels and the other two components of working memory: maintenance and resistance to distraction. The significant relationship between GABA levels and working memory load was specific to GABA in the dorsolateral prefrontal cortex as no such relationship was observed in the visual cortex or between levels of glutamine plus glutamate and working memory load.

\section{Working memory decline in aging}

Accumulating evidence indicates that, during normal aging, executive functions supported by the prefrontal cortex, including working memory, are among the earliest and most severely impaired cogni- 
tive abilities (Salthouse et al., 2003). Working memory in humans declines longitudinally with age, and aged individuals perform significantly worse than young (Nagel et al., 2009). In humans and primates, the total number of prefrontal cortex cells is preserved in aging (Peters et al., 1996). There is, however, evidence of significant age-related changes in neuronal morphology, including apical dendritic regression, loss of synapses, and a decrease in spine number (Peters et al., 1996; Bloss et al., 2013). Moreover, inhibitory circuits in the prefrontal cortex are vulnerable to age-related changes that may underlie cognitive decline at advanced age. These changes include increased expression of GAD, the critical enzyme for GABA synthesis, altered expression of $\mathrm{GABA}_{\mathrm{B}}$ receptors, and reduced expression of GAT-1, the GABA transporter responsible for the reuptake of GABA at the synapse, in aged prefrontal cortex compared with young (Bañuelos et al., 2014). In contrast to Yoon et al. (2016), increased inhibition in the prefrontal cortex negatively affects working memory performance in aged rats, implying that the relationship between GABAergic drive and cognitive performance differs in an age-dependent manner. The loss of tonic presynaptic $\mathrm{GABA}_{\mathrm{B}}$ autoreceptor activation in layer $2 / 3$ pyramidal cells in the prefrontal cortex of aged rats supports this premise (Carpenter et al., 2016). Together, these data suggest that there is an optimal inhibitory state in the young and aged prefrontal cortex, and any deviation from this state could adversely affect the cognitive processes mediated by this area.

The balance between excitation and inhibition is crucial for optimal cognitive functioning and maintaining network oscillations that support these capacities. An emerging literature demonstrates that, in aging, significant changes in both excitatory and inhibitory synaptic transmission may be related to cognitive impairment (Bories et al., 2013). Theta $(4-8 \mathrm{~Hz})$ and gamma (20$100 \mathrm{~Hz}$ ) oscillations, neural oscillations that have been linked to information processing and cognition, are attenuated in certain behavioral conditions in aging (Jacobson et al., 2013). The coupling of theta and gamma oscillations, which supports cognitive processes, is also decreased in aged rats (Jacobson et al., 2013). In humans, gamma oscillatory power is positively correlated with working memory load (Howard et al., 2003). Moreover, gamma band dynamics are decreased in older adults in association with poor working memory (Missonnier et al., 2010).
Gamma oscillations are directly linked to the firing of fast-spiking parvalbuminexpressing GABAergic interneurons (Sohal et al., 2009). Therefore, more GABA, as reported by Yoon et al. (2016), would be predicted to facilitate the modulation of neuronal rhythms during cognitive engagement.

In a recently published study, Porges et al. (2017) used a technique similar to Yoon et al. (2016) to measure in vivo GABA levels in young and older individuals that were assessed on the Montreal Cognitive Assessment. They found that GABA concentrations in both frontal and posterior regions declined with age. Interestingly, in line with Yoon et al. (2016), after controlling for age, years of education, and brain atrophy, greater frontal GABA concentrations were associated with superior cognitive performance. This study assessed general cognitive function and did not look at specific frontal regions. Extending the approach of Yoon et al. (2016) to include a direct assessment specifically of dorsolateral prefrontal cortex GABA levels in relation to working memory performance in older individuals would shed new light on how GABA levels change with age, in relation to age-related working memory deficits.

It is noteworthy that the study by Yoon et al. (2016) included both males and females but sex differences in working memory performance or GABA levels were not reported. Nonetheless, significant sex effects have been reported previously (Epperson et al., 2002; Harness et al., 2008). In longitudinal studies of cognitive aging, older women displayed greater resilience to age-related cognitive decline compared with male counterparts (McCarrey et al., 2016). It would therefore be valuable to examine the relationship between sex, cortical GABA levels, and working memory performance in aging.

The use of magnetic resonance spectroscopy imaging, as outlined by Yoon et al. (2016), to assess neural substrates, such as GABA in vivo in humans, may be a useful tool to study the integrity of excitatory/ inhibitory influences in specific brain regions in relation to cognitive ability across the lifetime. Data from such studies may point to novel therapeutic targets for treating cognitive deficits in aging that aim to restore homeostasis at advanced age. Most currently available treatments for age-related cognitive decline target excitatory circuitry; and although patients with mild cognitive impairment show improved performance on explicit memory tasks, this therapeutic approach appears to be effective for a relatively short time after initiation of treatment (Jacqueline and Leon, 2006; Schneider et al., 2011). Therefore, there is a great need to develop novel therapeutic approaches. Targeting inhibitory GABAergic systems pharmacologically, with transcranial magnetic stimulation or by other directed techniques, may be such an approach.

\section{References}

Bañuelos C, Beas BS, McQuail JA, Gilbert RJ, Frazier CJ, Setlow B, Bizon JL (2014) Prefrontal cortical GABAergic dysfunction contributes to age-related working memory impairment. J Neurosci 34:3457-3466. CrossRef Medline

Bloss EB, Puri R, Yuk F, Punsoni M, Hara Y, Janssen WG, McEwen BS, Morrison JH (2013) Morphological and molecular changes in aging rat prelimbic prefrontal cortical synapses. Neurobiol Aging 34:200-210. CrossRef Medline

Bories C, Husson Z, Guitton MJ, De Koninck Y (2013) Differential balance of prefrontal synaptic activity in successful versus unsuccessful cognitive aging. J Neurosci 33:1344-1356. CrossRef Medline

Carpenter HE, Kelly KB, Bizon JL, Frazier CJ (2016) Age-related changes in tonic activation of presynaptic versus extrasynaptic $\gamma$-aminobutyric acid type $B$ receptors in rat medial prefrontal cortex. Neurobiol Aging 45:88-97. CrossRef Medline

Constantinidis C, Goldman-Rakic PS (2002) Correlated discharges among putative pyramidal neurons and interneurons in the primate prefrontal cortex. J Neurophysiol 88: 3487-3497. CrossRef Medline

Enomoto T, Tse MT, Floresco SB (2011) Reducing prefrontal gamma-aminobutyric acid activity induces cognitive, behavioral, and dopaminergic abnormalities that resemble schizophrenia. Biol Psychiatry 69:432-441. CrossRef Medline

Epperson CN, Haga K, Mason GF, Sellers E, Gueorguieva R, Zhang W, Weiss E, Rothman DL, Krystal JH (2002) Cortical gamma-aminobutyric acid levels across the menstrual cycle in healthy women and those with premenstrual dysphoric disorder: a proton magnetic resonance spectroscopy study. Arch Gen Psychiatry 59:851-858. CrossRef Medline

Fuster JM (1990) Behavioral electrophysiology of the prefrontal cortex of the primate. Prog Brain Res 85:313-323; discussion 323-324. Medline

Goldman-Rakic PS (1990) Cellular and circuit basis of working memory in prefrontal cortex of nonhuman primates. Prog Brain Res 85: 325-335. Medline

Goldman-Rakic PS (1996) Regional and cellular fractionation of working memory. Proc Natl Acad Sci U S A 93:13473-13480. CrossRef Medline

Harness A, Jacot L, Scherf S, White A, Warnick JE (2008) Sex differences in working memory. Psychol Rep 103:214-218. CrossRef Medline

Howard MW, Rizzuto DS, Caplan JB, Madsen JR, Lisman J, Aschenbrenner-Scheibe R, SchulzeBonhage A, Kahana MJ (2003) Gamma oscillations correlate with working memory load 
in humans. Cereb Cortex 13:1369-1374. CrossRef Medline

Jacobson TK, Howe MD, Schmidt B, Hinman JR, Escabí MA, Markus EJ (2013) Hippocampal theta, gamma, and theta-gamma coupling: effects of aging, environmental change, and cholinergic activation. J Neurophysiol 109: 1852-1865. CrossRef Medline

Jacqueline B, Leon F (2006) Donepezil for mild cognitive impairment. In: Cochrane database of systematic reviews. New York: Wiley.

Lewis DA, Hashimoto T, Volk DW (2005) Cortical inhibitory neurons and schizophrenia. Nat Rev 6:312-324. CrossRef Medline

McCarrey AC, An Y, Kitner-Triolo MH, Ferrucci L, Resnick SM (2016) Sex differences in cognitive trajectories in clinically normal older adults. Psychol Aging 31:166-175. CrossRef Medline

Miller EK, Cohen JD (2001) An integrative theory of prefrontal cortex function. Annu Rev Neurosci 24:167-202. CrossRef Medline

Missonnier P, Herrmann FR, Michon A, Fazio-
Costa L, Gold G, Giannakopoulos P (2010) Early disturbances in gamma band dynamics in mild cognitive impairment. J Neural Transm 117:489-498. CrossRef Medline

Murray AJ, Woloszynowska-Fraser MU, AnselBollepalli L, Cole KL, Foggetti A, Crouch B, Riedel G, Wulff P (2015) Parvalbuminpositive interneurons of the prefrontal cortex support working memory and cognitive flexibility. Sci Rep 26:16778. CrossRef Medline

Nagel IE, Preuschhof C, Li SC, Nyberg L, Bäckman L, Lindenberger U, Heekeren HR (2009) Performance level modulates adult age differences in brain activation during spatial working memory. Proc Natl Acad Sci U S A 106: 22552-22557. CrossRef Medline

Peters A, Rosene DL, Moss MB, Kemper TL, Abraham CR, Tigges J, Albert MS (1996) Neurobiological bases of age-related cognitive decline in the rhesus monkey. J Neuropathol Exp Neurol 55:861-874. CrossRef Medline

Porges EC, Woods AJ, Edden RA, Puts NA, Harris $\mathrm{AD}$, Chen H, Garcia AM, Seider TR, Lamb
DG, Williamson JB, Cohen RA (2017) Frontal gamma-aminobutyric acid concentrations are associated with cognitive performance in older adults. Biol Psychiatry Cogn Neurosci Neuroimaging 2:38-44. CrossRef Medline

Salthouse TA, Atkinson TM, Berish DE (2003) Executive functioning as a potential mediator of age-related cognitive decline in normal adults. J Exp Psychol Gen 132:566-594. CrossRef Medline

Schneider LS, Dagerman KS, Higgins JP, McShane R (2011) Lack of evidence for the efficacy of memantine in mild Alzheimer disease. Arch Neurol 66:991-998. CrossRef Medline

Sohal VS, Zhang F, Yizhar O, Deisseroth K (2009) Parvalbumin neurons and gamma rhythms enhance cortical circuit performance. Nature 459: 698-702. CrossRef Medline

Yoon JH, Grandelis A, Maddock RJ (2016) Dorsolateral prefrontal cortex GABA concentration in humans predicts working memory load processing capacity. J Neurosci 36:11788-11794. CrossRef Medline 